\title{
Synthetic Studies of Naphtho[2,3-b]furan Moiety Present in Diverse Bioactive Natural Products
}

\author{
Bidyut Kumar Senapati1 ${ }^{*}$, Dipakranjan Mal $^{2}$ \\ ${ }^{1}$ Department of Chemistry, Prabhat Kumar College, Contai, India \\ ${ }^{2}$ Department of Chemistry, Indian Institute of Technology, Kharagpur, India \\ Email: bsenapati79@gmail.com
}

Received 5 April 2015; accepted 26 May 2015; published 29 May 2015

Copyright (C) 2015 by authors and Scientific Research Publishing Inc.

This work is licensed under the Creative Commons Attribution-NonCommercial 4.0 International License

(CC-BY-NC).

http://creativecommons.org/licenses/by-nc/4.0/

(c) (i) (\$) Open Access

\begin{abstract}
The preparation of several functionalized furan derivatives and attempts to transform them into a derivative containing $6 H$-furo[3,4-b]furanone skeleton towards the construction of naphtho[2,3-b] furan are described. Attempted Pummerer reaction of a furan sulfoxide derivative produced four interesting furan derivatives. Base promoted annulation between methyl 2-(phenylsulfinylmethyl)-3-furoate and 2-cyclohexenone proceeded to give dihydro naphtho[2,3-b]furanone derivative in a regiospecific manner.
\end{abstract}

\section{Keywords}

6H-Furo[3,4-b]furanone, Naphtho[2,3-b]furan, Intramolecular Pummerer Reaction, Desulfanylation, Lactonization

\section{Introduction}

Functionally embellished naphtho[2,3-b]furan moiety has been widely encountered as a unique sub-structure among a diverse range of bioactive synthetic molecules and natural products. Particularly, the condensed quinone derivatives of naphtho[2,3- $b]$ furans such as furonaphthoquinones have been proved to possess broad anticancer activities [1]. Recently, M. Koketsu and co-workers reported that the synthetic furonaphthoquinones showed moderate cytotoxicity against human leukemia U937 and HL-60 cells [2]. During the past decades, a wide range of furanoid natural products have been isolated from plant sources. Among these, furonapthoqui-

\footnotetext{
*Corresponding author.
}

How to cite this paper: Senapati, B.K. and Mal, D. (2015) Synthetic Studies of Naphtho[2,3-b]furan Moiety Present in Diverse Bioactive Natural Products. International Journal of Organic Chemistry, 5, 63-74. 
nones (e.g. 1 - 9) are prominent due to their wide biological activities and structural significance (Figure 1). Although some strategies have been used for the construction of furonaphthoquinone skeletons, most of the reported methods employ multistep to secure the target skeletons from readily available precursors [3]. Hence intense research in this area has been carried out in recent years leading to the development of simple and straightforward regiospecific route for the preparation of functionalized furonaphthoquinone compounds [4].

Our continued interest in the application of anionic [4 +2] cylcoaddition [5] of isobenzofuranones prompted us to study the preparation of $6 H$-furo[3,4-b]furanones (10) towards the construction of naphtho[2,3-b]furan skeleton embedded in various biologically important molecules.

\section{Results and Discussion}

Our study began with the preparation of furanosulfoxide derivative 14, following the literature procedure [6]. Bromination of methyl 2-methyl-furan-3-carboxylate (11) with $N$-bromosuccinimide (NBS) under standard condition gave bromo derivative $\mathbf{1 2}$ was prepared in 75\% yield. Reaction of compound $\mathbf{1 2}$ with sodium methoxide and thiophenol gave compound $\mathbf{1 3}$ in $88 \%$ yield followed by oxidation with sodium periodate in methanol and water medium provided methyl 2-(phenylsulfinylmethyl)-3-furoate (14a) in 75\% yield (Scheme 1). Attempted intramolecular Pummerer reaction [7] of sulfoxide 14a with trimethylsilyl chloride (TMSCl) in dichloromethane for overnight, no reaction took place. But when this was refluxed with acetic anhydride, a polymeric product generated. When compound 14a was refluxed with trifluro acetic anhydride or $p$-toluenesulfonic acid (PTSA), complex mixtures of products were obtained. Examination of the ${ }^{1} \mathrm{H}$ NMR spectrum of the crude products did not indicate formation of desired 10a. The same result was obtained when the above reactions were performed on acid derivative 14b, prepared by hydrolysis of sulfoxide ester 14a with aqueous $\mathrm{NaOH}$ and ethanol.

For Scheme 1. Reagents and conditions: (i) NBS, $\mathrm{CCl}_{4},(\mathrm{PhCO})_{2} \mathrm{O}_{2}$ (cat.), hv, 75\%; (ii) $\mathrm{PhSH}, \mathrm{NaI}, \mathrm{MeOH}$, reflux, 88\%; (iii) $\mathrm{NaIO}_{4}, \mathrm{MeOH} / \mathrm{H}_{2} \mathrm{O}$, rt, 40 h, $75 \%$; (iv) $\mathrm{NaOH}$, ethanol, $85 \%$; (v) $\mathrm{TMSCl}, \mathrm{CH}_{2} \mathrm{Cl}_{2}$, overnight or (vi) $\mathrm{Ac}_{2} \mathrm{O}$, reflux, $10 \mathrm{~h}$ or (vii) $\left(\mathrm{CF}_{3} \mathrm{CO}\right)_{2} \mathrm{O}$, reflux or PTSA, reflux.

Interestingly, treatment of sulfoxide 14a with acetic anhydride and a catalytic amount of sodium acetate under reflux produced four different products instead of 10a. All these products 15, 16, 17 and 18 were separated by column chromatography and characterized by NMR, IR studies. Under the same conditions the acid derivative 14b produced an oily polymeric product, ${ }^{1} \mathrm{H}$ NMR spectrum of which revealed the absence of 10a.<smiles>[R]Oc1cccc2c1C(=O)c1ccoc1C2=O</smiles>

Diodantunezone (1)<smiles>O=C1c2ccccc2C(=O)c2c1oc1c(CO)coc21</smiles>

3-hydroxymethylfuro[3,2-b]naphtho-[2,3-d]furan 5,10-dione (4)

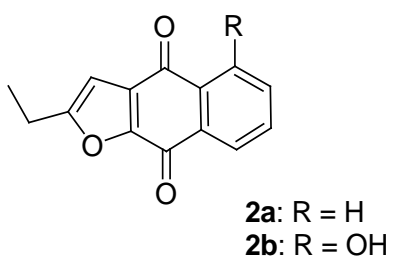

2-Ethyl furonaphthoquinone (2)<smiles>CC(C)=CC1(C)CC2=C(O1)C(=O)c1ccccc1C2=O</smiles><smiles>[R]c1ccc2c(c1[R])C(=O)C1=C(O[C@H](C(=C)C)[C@H]1[R])C2=O</smiles>

$\alpha$-lapachone (7) 7a: $\mathrm{R}_{1}=\mathrm{R}_{2}=\mathrm{OMe}, \mathrm{R}_{3}=\mathrm{OH}$

7b: $R_{1}=R_{2}=O M e, R_{3}=H$

7c: $R_{1}=R_{2}=H, R_{3}=O M e$<smiles>Cc1coc2c(O)c3c(c(C)c12)[C@@H](C)CCC3</smiles>

cacalol (8)<smiles>[R]Oc1cccc2c1C(=O)c1cc([C@@H](C)O)oc1C2=O</smiles>

2-(1-hydroxyethyl)naphtho[2,3-b]-furan-4,9-dione (6)

Figure 1. Structure of some biologically active naphtho[2,3-b]furan harbouring natural products. 
For Scheme 3. Reagents and conditions: (viii) $\mathrm{Ac}_{2} \mathrm{O}$, $\mathrm{NaOAc}$, reflux, 3 h, 28\% (for 15), 8\% (for 16), 6\% (for 17) and $15 \%$ (for 18).

Except 18, all these products were expectedly generated through a common Pummerer intermediate 19. Nucleophilic addition of water to the Pummerer intermediate 19 and subsequent expulsion of thiophenol gave aldehydic ester derivative $\mathbf{1 5}$ as the major product (28\%). Compound 15 could further be added to acetic anhydride to produce furan diacetate derivative $\mathbf{1 6}$ in $8 \%$ yield (Scheme 2).

Formation of compound 17 (6\%) could be explained by addition of one equivalent of thiophenol to the common intermediate 19. On the other hand, the acetate derivative 18 (15\%) could be formed by direct nucleophilic displacement of sulfoxide group of 14a by acetate anion.

Having been successful with the above Scheme 3, we focused our attempts to convert ethylsulfoxide 21a to furofuranone 10b via an intramolecular Pummerer reaction. It was presumed that the corresponding intermediate would have favorable geometry for an intramolecular Pummerer reaction [8]. Compound $\mathbf{1 2}$ was converted to 20 in $87 \%$ yield by the treatment with sodium methoxide and ethanethiol in refluxing methanol. Oxidation of 20 with sodium periodate gave two products which were separated using column chromatography (1:4 mixture of ethyl acetate/petroleum ether). After column chromatography, the desired ethylsulfoxide 21a as isolated in 56\% yield and the more oxidized ethylsulfone 21b was isolated in 33\% yield as shown in Scheme 4. Both the com pounds 21a and 21b were fully characterized on the basis of spectroscopic (IR, NMR and mass spectral data) analysis. The ${ }^{1} \mathrm{H}$ NMR spectrum exhibited two doublets, one at $\delta 7.40(1 \mathrm{H})$ and other at $\delta 6.73(1 \mathrm{H})$ for furan ring. It also showed an $\mathrm{ABq}$ signal at $\delta 4.44(2 \mathrm{H})$ corresponding to two $\alpha$-hydrogen atoms of ethylsulfoxide group. But, all attempts to effect intramolecular Pummerer reaction of 21a with various reagents such as PTSA in $\mathrm{C}_{6} \mathrm{H}_{6}$, $\mathrm{Ac}_{2} \mathrm{O}$ in toluene, $\left(\mathrm{CF}_{3} \mathrm{CO}\right)_{2} \mathrm{O}$ in $\mathrm{CH}_{2} \mathrm{Cl}_{2}, \mathrm{CF}_{3} \mathrm{CO}_{2} \mathrm{H}$, pyridinium PTSA in refluxing condition and phenyliodine

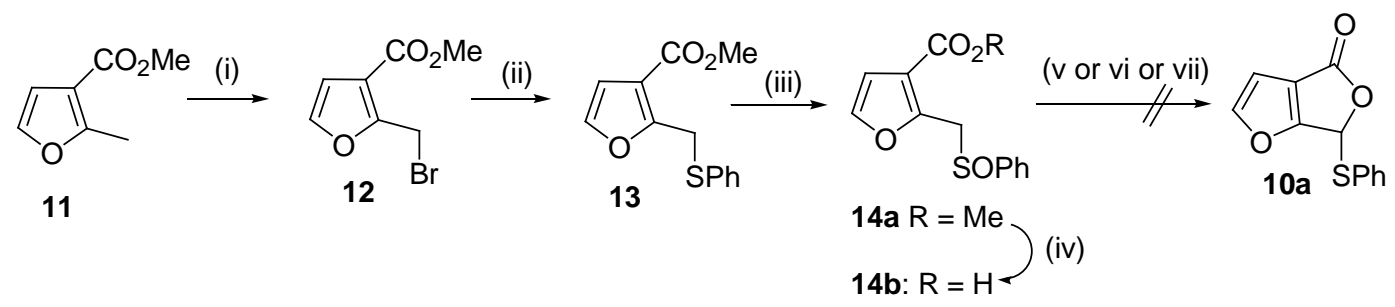

Scheme 1. Synthetic approach to furo[3,4-b]furanone derivative 10a.<smiles>COC(=O)c1ccoc1COc1ccccc1CSOc1ccccc1</smiles>

18<smiles>CCCC(O)(c1ccccc1)c1oc(C=O)cc1C(=O)O</smiles><smiles>COC(=O)c1ccoc1C=O</smiles>

Pummerer intermediate<smiles>COC(=O)c1ccoc1C(c1ccccc1)c1ccccc1</smiles>

17<smiles>CC(=O)Cc1ccoc1C(OC(C)=O)OC(C)=O</smiles>

Scheme 2. Possible pathway for the formation of compounds 15, 16, 17 and 18.

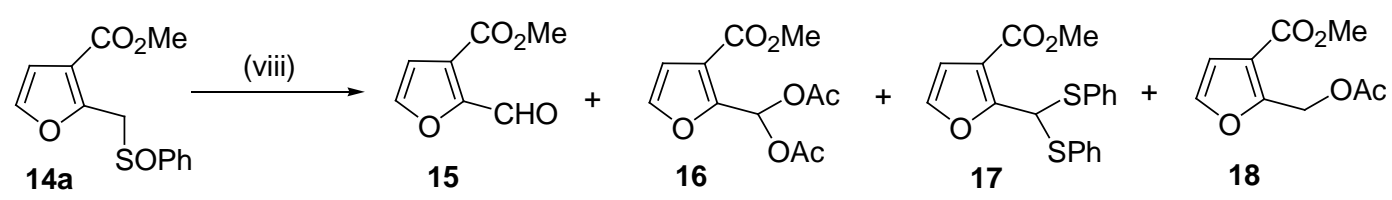

Scheme 3. Intramolecular Pummerer reaction of 14a. 


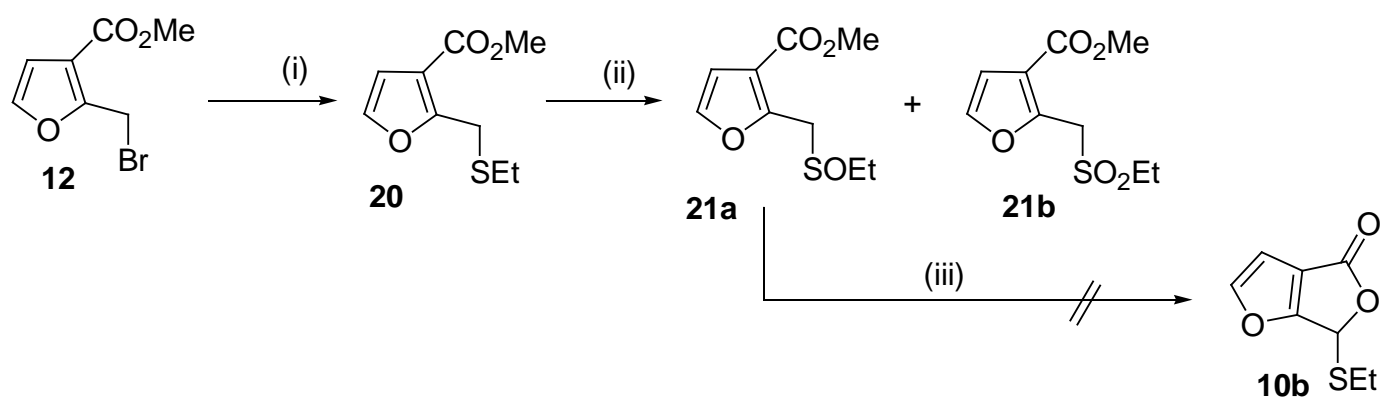

Scheme 4. Attempted intramolecular Pummerer reaction for the formation of $\mathbf{1 0 b}$.

diacetate (PIDA) in $\mathrm{CH}_{2} \mathrm{Cl}_{2}$ failed to give the expected furofuranone 10b. In all the cases the ${ }^{1} \mathrm{H}$ NMR spectrum of the crude products consisted of broadened signals indicating polymeric materials.

For Scheme 4. Reagents and conditions: (i) $\mathrm{EtSH}, \mathrm{CHCl}_{3}, \mathrm{Et}_{3} \mathrm{~N}$, rt, overnight, $87 \%$; (ii) $\mathrm{NaIO}_{4}, \mathrm{MeOH}, 0^{\circ} \mathrm{C}, 2$ h, 56\%; (iii) PTSA in $\mathrm{C}_{6} \mathrm{H}_{6}$, reflux, $10 \mathrm{~h}$ or $\mathrm{Ac}_{2} \mathrm{O}$ in toluene, reflux, $10 \mathrm{~h}$ or $\left(\mathrm{CF}_{3} \mathrm{CO}\right)_{2} \mathrm{O}$ in $\mathrm{CH}_{2} \mathrm{Cl}_{2}$, reflux, $12 \mathrm{~h}$ or $\mathrm{CF}_{3} \mathrm{CO}_{2} \mathrm{H}$, pyridinium PTSA, reflux, $12 \mathrm{~h}$ or PIDA in $\mathrm{CH}_{2} \mathrm{Cl}_{2}$, reflux, $12 \mathrm{~h}$.

Following the above failures, we turned to preparing furan sulfoxide derivative $\mathbf{2 6}$ starting from 3-furoic acid and chloromethylsulfanylbenzene (24) and examining its intramolecular cyclisation via Pummerer reaction to obtain 10a. Methylation of thiophenol with sodium hydroxide and dimehylsulfate in acetone under reflux condition gave $\mathbf{2 3}$ in $87 \%$ yield. Treatment of $\mathbf{2 3}$ with $\mathrm{N}$-chlorosuccinimide in $\mathrm{CCl}_{4}$ produced $\mathbf{2 4}$ in $82 \%$ yield. Then compound $\mathbf{2 4}$ was reacted with 3-furoic acid (25) in the presence of DBU to give $\mathbf{2 6}$ (70\% yield). This was then transformed to sulfoxide $\mathbf{2 7}$ (76\% yield) by sodium periodate $\left(\mathrm{NaIO}_{4}\right)$ oxidation. Both the compounds $\mathbf{2 6}$ and $\mathbf{2 7}$ gave satisfactory IR, ${ }^{1} \mathrm{H}$ NMR and ${ }^{13} \mathrm{C}$ NMR spectroscopic data. The ${ }^{1} \mathrm{H}$ NMR spectrum showed an ABq signal at $\delta 5.14(2 \mathrm{H})$ corresponding to two $\alpha$-hydrogen atoms of phenylsulfoxide group. Several Pummerer reagents (vide reagents of Scheme 5) were employed for the intramolecular cyclization of 27, but none were effective to give 10a as shown in Scheme 5.

For Scheme 5. Reagents and conditions: (i) aq. $\mathrm{NaOH}, \mathrm{Me}_{2} \mathrm{SO}_{4}$, reflux, 4 h, $87 \%$; (ii) NCS, $\mathrm{CCl}_{4}$, rt, $11 \mathrm{~h}$, 82\%; (iii) DBU, $\mathrm{CH}_{3} \mathrm{CN}, 4 \mathrm{~h}, 70 \%$; (v) $\mathrm{NaIO}_{4}, \mathrm{MeOH}, 5 \mathrm{~h}, 76 \%$; (vi) $p$ - $\mathrm{TsOH}$ in $\mathrm{C}_{6} \mathrm{H}_{6}$, reflux, $10 \mathrm{~h}$ or $\mathrm{Ac}_{2} \mathrm{O}$ in toluene, reflux, $10 \mathrm{~h}$ or $\left(\mathrm{CF}_{3} \mathrm{CO}\right)_{2} \mathrm{O}$ in $\mathrm{CH}_{2} \mathrm{Cl}_{2}$, reflux, $12 \mathrm{~h}$ or $\mathrm{CF}_{3} \mathrm{CO}_{2} \mathrm{H}$, pyridinium PTSA, reflux, $12 \mathrm{~h}$.

As we failed to achieve the preparation of furofuranone 10a by Pummerer procedures, we modified our approach to synthesizing 10a through the desulfanylation of $\mathbf{1 7}$, in view of the success of this type of cyclization in benzene system reported by Hauser et al. [8]. Treatment of compound $\mathbf{1 5}$ with thiophenol and catalytic amounts of TMSCl in chloroform solvent produced $\mathbf{1 7}$ in 85\% yield (Scheme 6). Attempted cyclization of $\mathbf{1 7}$ in trifluoroacetic acid under reflux condition failed to give expected compound 10a. ${ }^{1} \mathrm{H}$ NMR spectrum of the crude product revealed that starting material decomposed during the course of reaction.

For Scheme 6. Reagents and conditions: (i) $\mathrm{PhSH}$, TMSCl, $\mathrm{CHCl}_{3}$, rt, 85\%; (ii) $\mathrm{CF}_{3} \mathrm{CO}_{2} \mathrm{H}, \mathrm{H}_{2} \mathrm{O}$, reflux, $12 \mathrm{~h}$.

As we could not carry out the above cyclization of $\mathbf{1 7}$, we thought that compound $\mathbf{3 2}$ might suit for this desulfanylation reaction due to lesser effect of nuclear oxygen atom. It was prepared in good yield starting from commercially available methyl 3-methyl-furan-2-carboxylate (28). The sequence is depicted in Scheme 7. NBS bromination of 28 produced dibromo derivative 29 (60\%) along with monobromo derivative 30 in 25\% yield. These compounds were separated using column chromatography methods ( $1: 4$ mixture of $\mathrm{CHCl}_{3} /$ petroleum ether). Hydrolysis of dibromo derivative $\mathbf{2 9}$ with silver nitrate in $\mathrm{THF} / \mathrm{H}_{2} \mathrm{O}$ produced furan-3-carboxaldehyde $\mathbf{3 1}$ in $42 \%$ yield. Finally, treatment of $\mathbf{3 1}$ with thiophenol and a catalytic amount of TMSCl provided compound 32. Attempted desulfanylation of $\mathbf{3 2}$ with trifluoroacetic acid and water in reflux condition failed to give expected product 10c, starting material was recovered exclusively meaning that no reaction took place.

For Scheme 7. Reagents and conditions: (i) NBS (2 equiv.), $\mathrm{CCl}_{4}$, benzoyl peroxide, $\mathrm{h} v, 60 \%$ (for 29) and 25\% (for 30); (ii) $\mathrm{AgNO}_{3}$, THF, $\mathrm{H}_{2} \mathrm{O}$, 42\%; (iii) $\mathrm{PhSH}, \mathrm{TMSCl}, \mathrm{CHCl}_{3}$, rt, 80\%; (iv) $\mathrm{CF}_{3} \mathrm{CO}_{2} \mathrm{H}, \mathrm{H}_{2} \mathrm{O}$, reflux, $12 \mathrm{~h}$.

At this point, we investigated the coupling reaction between diazo derivative of tetronic acid (36) and vinyl acetate for synthesizing $\mathbf{3 7}$ from which desired furo[3,4-b]furanone system could be obtained. Compound $\mathbf{3 6}$ was prepared from tosyl azide (34) and tetronic acid (35) in the presence of triethylamine according to the literature procedure in $40 \%$ yield [9]. ${ }^{1} \mathrm{H}$ NMR of 36 showed only one singlet at $\delta 4.70(2 \mathrm{H}, \mathrm{s})$ corresponding to $-\mathrm{CH}_{2}$ group. Then we examined its coupling with vinyl acetate under various conditions (Scheme 8) [10]. But 


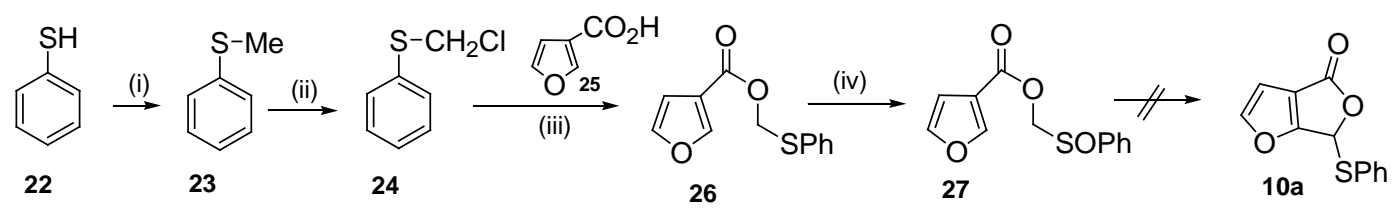

Scheme 5. Attempted intramolecular Pummerer reaction for the synthesis of 10a.

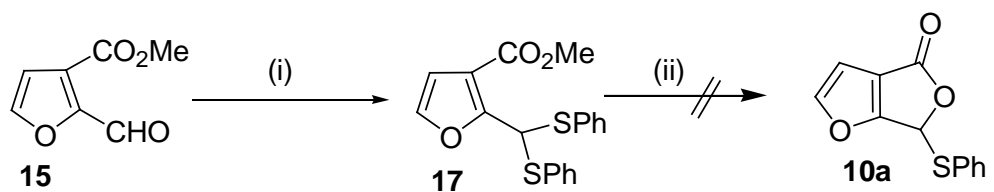

Scheme 6. Attempted intramolecular desulfanylation of $\mathbf{1 7}$ to obtain 10a.<smiles>Cc1ccoc1C([18O])(Cl)c1ccccc1</smiles>

10c (i)<smiles></smiles><smiles>CC#CC</smiles><smiles>COC(=O)c1occc1C(c1ccccc1)c1ccccc1</smiles>

32<smiles>COC(=O)c1occc1C(Br)Br</smiles>

$+$<smiles>COC(=O)c1occc1CBr</smiles>

30

(ii)<smiles>COC(=O)c1oc(C=O)cc1C=O</smiles>

31

Scheme 7. Investigation of intramolecular desulfanylation of 32.<smiles>Cc1ccc(S(=O)(=O)Cl)cc1</smiles>

33<smiles>CC(C)(C)OC1CC(=O)CO1</smiles>

34<smiles>N=C1C(=O)COC1=O</smiles>

36<smiles>CC(=O)OC1CC2=C(COC2=O)O1</smiles>

37

Scheme 8. Attempted routes to synthesis of 37.

unfortunately, all the attempts failed to give 37. Examination of ${ }^{1} \mathrm{H}$ NMR spectrum of the crude product indicated the exclusive presence of starting material in first two cases (with rhodium diacetate or ceric ammonium nitrate) and unidentifiable product mixture of products with PIDA treatment.

For Scheme 8. Reagents and conditions: (i) $\mathrm{NaN}_{3}$, aq. Acetone, rt, 85\%; (ii) $\mathrm{Et}_{3} \mathrm{~N}, \mathrm{CH}_{3} \mathrm{CN}, 40 \%$; (iii) $\mathrm{Rh}_{2}(\mathrm{OAc})_{2}$ or $\mathrm{CAN}, \mathrm{CH}_{3} \mathrm{CN}, 0^{\circ} \mathrm{C}$ or $\mathrm{PhI}(\mathrm{OAc})_{2}$.

Again we modified our route for the synthesis of furolactone 10d, from which desired compound 10a may be prepared. The hydroxy ester derivative 38 was prepared from 12 by heating it at $80^{\circ} \mathrm{C}$ in dimetyl sulfoxide and water. The NMR data of $\mathbf{3 8}$ matched with literature value [11]. Then compound $\mathbf{3 8}$ was transformed to 2-hydroxymethyl-furan-3-carboxylic acid (39) in $90 \%$ yield by the treatment of $40 \%$ aqueous solution of $\mathrm{KOH}$ solution in methanol (Scheme 9).

For Scheme 9. Reagents and conditions: (i) DMSO, $80^{\circ} \mathrm{C}, 4$ h, $92 \%$; (ii) $\mathrm{KOH}, \mathrm{H}_{2} \mathrm{O}, \mathrm{MeOH}, 90 \%$; (iii) attempted lactonization with $\mathrm{SOCl}_{2}$ in $\mathrm{CH}_{2} \mathrm{Cl}_{2}$, DCC in DMF or in $\mathrm{CH}_{2} \mathrm{Cl}_{2}, \mathrm{Ac}_{2} \mathrm{O}$ in toluene under refluxing condition and $\mathrm{BF}_{3}$-ether in $\mathrm{C}_{6} \mathrm{H}_{6}$.

We then investigated lactonization of compound 39 with various well established literature methods. But, all 
attempts for lactonization of $\mathbf{3 9}$ failed to give the expected furolactone 10d as shown in Scheme 9. In all the cases except with $\mathrm{SOCl}_{2},{ }^{1} \mathrm{H}$ NMR spectrum of the crude products showed exclusive presence of the starting material 39, meaning no reaction took place. Reaction with $\mathrm{SOCl}_{2}$ produced intractable mixture of products which could not be identified by NMR studies. The above failure of the lactonization may be attributed due to the unfavorable distance between carbonyl "C" and hydroxyl "O" atoms in $\mathbf{3 9}$ compared to that in its benzene analog $\mathbf{4 0}$ (Figure 2) where lactonization is very facile. Geometries of molecules $\mathbf{3 9}$ and $\mathbf{4 0}$ were minimized by using density functional theory (DFT) calculations based on the BLYP level of theory with the DND basis set using $\mathrm{DMol}^{3}$ package program [12].

Then we thought that sulfoxide 14a itself may serve the purpose of furan annulating agents (i.e. 10a or 10b) for the synthesis of naphtho[2,3-b]furan skeleton. For that purpose, when the sulfoxide 14a was treated with lithium tert-butoxide ( $t$-BuOLi), a light yellow color developed, indicating the generation of carbanion $\alpha$ to -SOPh group, and subsequently the color of the reaction mixture changed to light brown upon addition of 2-cyclohexenone. Work up of the reaction mixture led to formation of tricyclic compound $\mathbf{4 2}$ as white solid in $\mathbf{7 \%}$ yield (Scheme 10). Further transformation of compound $\mathbf{4 2}$ to desired naphtho[2,3-b]furan derivative was postponed due to poor yield. We were able to taken only ${ }^{1} \mathrm{H}$ NMR and IR spectrum of this compound. The ${ }^{1} \mathrm{H}$ NMR spectrum exhibited three multiplets of six protons at the region of $\delta 2.18-2.97$, corresponding to the cyclohexane ring and two doublets, one at $\delta 7.49(1 \mathrm{H})$ and other at $\delta 6.94(1 \mathrm{H})$ for furan ring. It also showed a ${ }^{1} \mathrm{H}$ sharp singlet at $\delta 13.51$ corresponding to hydrogen bonded ' $\mathrm{OH}$ ' group. We repeated the above annulation three times without any improvement in the yield. We also performed this cylcoaddition reaction in presence of lithium diisopropyl amide (LDA). But, ${ }^{1} \mathrm{H}$ NMR spectrum of the crude indicated the formation of a polymeric material.

\section{Conclusion}

With the aim of preparing novel naphtho[2,3-b]furan derivatives, an investigation was carried out to synthesize, characterize and study furo[3,4-b]furanones by several approaches. The results showed that the intramolecular Pummerer reaction of furan sulfoxide derivative produced four interesting furan derivatives. The anionic cycloaddition between furan sulfoxide and 2-cyclohexenone produced dihydro naphtho[2,3-b]furanone derivative in<smiles>O=C(O)c1ccoc1CO[18OH]</smiles>

Total energy, $\mathrm{E}=-533.1953949$ a.u. Distance between C-1' and O-2" = 4.326 А<smiles>O=C(O)c1ccccc1C(=O)O</smiles>

Total energy, $\mathrm{E}=-535.3673350$ a.u.

Distance between C-1' and O-2" = 3.644 А

Figure 2. Comparison of distances between carbonyl "C $\mathrm{C}$ " and hydroxyl "O" atoms in $\mathbf{3 9}$ and $\mathbf{4 0}$.<smiles>COC(=O)c1ccoc1CBr</smiles>

Scheme 9. Attempted lactonization of 2-hydroxymethyl-furan-3-carboxylic acid (39).<smiles>COC(=O)c1ccoc1CSc1ccccc1</smiles>

$14 a$<smiles>O=C1C=CCCC1</smiles>

41

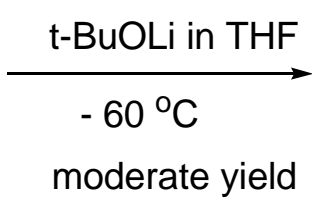

Scheme 10. Synthesis of dihydro naphtho[2,3-b]furanone moiety 42. 
poor yield. This study reveals that synthesis of simple looking furan derivatives (like 10a-d) was elusive and they deserve further study.

\section{Experimental}

\subsection{General}

Melting points were determined in open capillary tubes and are uncorrected. Among the spectra, ${ }^{1} \mathrm{H}$ NMR spectra and ${ }^{13} \mathrm{C}$-NMR spectra were recorded on $200 \mathrm{MHz}$ and $300 \mathrm{MHz}$ spectrometer (Brücker) as solution in ${ }^{2} \mathrm{H}-$ Chloroform with TMS as the internal standard. Chemical shifts are expressed in $\delta$ unit and ${ }^{1} \mathrm{H}-{ }^{1} \mathrm{H}$ coupling constant in Hz. IR spectra were recorded on a Thermo Nicolet Nexus 870 FT-IR spectrophotometers using $\mathrm{KBr}$ pellet. EI MS (70 eV) spectra were taken using a VG Autospec M mass spectrometer. Elemental analyses were carried out by using an elemental analyzer VARIO EL instrument. Dry solvents used for reactions were purified, before use, according to the standard protocols. All solvents for chromatography (column and preparative layer chromatography) were distilled prior to use.

\subsection{Methyl 2-(Phenylsulfinylmethyl)-3-furoate (14a)}

To a solution of compound 9 (5 g, $20 \mathrm{mmol})$ in $\mathrm{MeOH}(70 \mathrm{~mL})$ containing water $(15 \mathrm{~mL})$ was added solid $\mathrm{NaIO}_{4}$ (4.6 g, $21.5 \mathrm{mmol}$ ) in portions. The resultant mixture was stirred for $36 \mathrm{~h}$ at rt and the solvent was removed under reduced pressure. The resulting thick liquid was purified by column chromatography (3:7 ethyl acetate/petroleum ether, $\mathrm{R}_{\mathrm{f}} 0.48$ ) over silica gel to furnish the sulfoxide $\mathbf{1 4 a}(3.99 \mathrm{~g}, 75 \%)$ as pale yellow solid. mp. $84^{\circ} \mathrm{C}-85^{\circ} \mathrm{C}$ (lit. [6] mp. $85^{\circ} \mathrm{C}-86^{\circ} \mathrm{C}$ ); FT-IR (KBr) cm ${ }^{-1}$ 2935, 1714 (s), 1616, 1440 (m), 1387 (m), 1053, 756; ${ }^{1} \mathbf{H}$ NMR (200 MHz, $\mathrm{CDCl}_{3}$ ): $\delta 7.46-7.30(\mathrm{~m}, 5 \mathrm{H}), 7.32$ (d, 1H, $\left.J=2 \mathrm{~Hz}\right), 6.65$ (d, $1 \mathrm{H}, J=2 \mathrm{~Hz}$ ), 4.60 (d, $1 \mathrm{H}, J=12 \mathrm{~Hz}), 4.51$ (d, $1 \mathrm{H}, J=12 \mathrm{~Hz}), 3.70$ (s, 3H); ${ }^{13} \mathbf{C}$ NMR (50 MHz, CDCl $): \delta$ 163.1, 150.4, 142.9, 131.3, 128.9, 123.9, 117.5, 111.0, 55.6, 51.5; MS m/z (EI): $264\left(\mathrm{M}^{+}\right)$, 233, 186, 139 (100\%), 125, 109, 97, 77.

\subsection{2-Phenylsulfinylmethyl-furan-3-carboxylic Acid (14b)}

A mixture of methyl 2-(phenylsulfinylmethyl)-3-furoate 14a (1 g, $3.78 \mathrm{mmol}), 15 \mathrm{~mL}$ of $40 \%$ aqueous $\mathrm{NaOH}$ solution, $20 \mathrm{~mL}$ of $\mathrm{MeOH}$ and $15 \mathrm{~mL}$ of $\mathrm{H}_{2} \mathrm{O}$ were stirred for $5 \mathrm{~h}$ at ambient temperature. On completion of the reaction, the whole mixture was diluted with water $(40 \mathrm{~mL})$ and extracted with ethyl acetate $(3 \times 30 \mathrm{~mL})$. The combined organic layer was washed with water and $5 \%$ of $\mathrm{HCl}(20 \mathrm{~mL})$, brine $(20 \mathrm{~mL})$, dried $\left(\mathrm{Na}_{2} \mathrm{SO}_{4}\right)$ and concentrated. Purification of the crude residue by chromatography on $\mathrm{SiO}_{2}$ (1:1 ethyl acetate/petroleum ether, $\mathrm{R}_{\mathrm{f}}$ 0.32) gave compound $\mathbf{1 4 b}(0.8 \mathrm{~g}, 85 \%)$ as white solid. mp. $110^{\circ} \mathrm{C}-112^{\circ} \mathrm{C}$; FT-IR $(\mathrm{KBr}) \mathrm{cm}^{-1} 3412,2362,1709$ (s), 1601 (m), 1444, 1260, 1060, 746; ${ }^{1}$ H NMR (200 MHz,CDCl $): \delta 7.30$ (d, $\left.1 \mathrm{H}, J=2 \mathrm{~Hz}\right), 6.70$ (d, $1 \mathrm{H}, J=2$ $\mathrm{Hz}), 4.62(\mathrm{~d}, 1 \mathrm{H}, J=14 \mathrm{~Hz}), 4.53(\mathrm{~d}, 1 \mathrm{H}, J=14 \mathrm{~Hz}) ;{ }^{13} \mathbf{C}$ NMR $\left(50 \mathrm{MHz}, \mathrm{CDCl}_{3}\right): \delta 166.8,150.6,143.3,141.9$, 131.7, 129.2, 124.2, 117.9, 111.5, 55.2; HRMS: calcd. for $\mathrm{C}_{12} \mathrm{H}_{10} \mathrm{O}_{4} \mathrm{~S}[\mathrm{M}+\mathrm{Na}]^{+}$251.0380; found 251.0388.

\subsection{Methyl 2-Formyl-furan-3-carboxylate (15)}

To a stirred solution of $\mathbf{1 4 a}(1.0 \mathrm{~g}, 3.78 \mathrm{mmol}) \mathrm{Ac}_{2} \mathrm{O}(10 \mathrm{~mL})$ was added $\mathrm{NaOAc}(0.31 \mathrm{~g}, 3.78 \mathrm{mmol})$ and heated at $110^{\circ} \mathrm{C}$ for $3 \mathrm{~h}$. After completion of the reaction, the resulting mixture was diluted with water $(20 \mathrm{~mL})$ and extracted with ethyl acetate $(3 \times 20 \mathrm{~mL})$. The organic phases were washed with brine $(25 \mathrm{~mL})$, dried $\left(\mathrm{Na}_{2} \mathrm{SO}_{4}\right)$ and concentrated under reduced pressure. Purification of the crude residue by chromatography on silica gel (1:8 ethyl acetate/petroleum ether, $\mathrm{R}_{\mathrm{f}} 0.52$ ) gave 15 [13] (28\%) as white crystalline solid. $\mathbf{m p} .76^{\circ} \mathrm{C}$ 78 ${ }^{\circ} \mathrm{C}$; FT-IR (KBr) cm ${ }^{-1}$ 3145, 2886, 1719 (s), 1678 (s), 1575, 1404, 1308, 1212 (m), 1073, 1036, 809, 761; ${ }^{1} \mathbf{H}$ NMR (200 MHz, CDCl $)$ ): $\delta 10.21(\mathrm{~s}, 1 \mathrm{H}), 7.63(\mathrm{~d}, 1 \mathrm{H}, J=0.8 \mathrm{~Hz}), 6.88(\mathrm{~d}, 1 \mathrm{H}, J=0.8 \mathrm{~Hz}), 3.94(\mathrm{~s}, 3 \mathrm{H}) ;{ }^{13} \mathrm{C}$ NMR (50 MHz, $\left.\mathrm{CDCl}_{3}\right): \delta 178.7,161.9,152.4,146.7,126.2,112.8,52.5$.

\subsection{Methyl 2-Diacetoxymethyl-furan-3-carboxylate (16)}

This compound was obtained as white solid in $8 \%$ yield from 14a on treatment with $\mathrm{Ac}_{2} \mathrm{O}$ and $\mathrm{NaOAc}$, following the procedure adopted for the preparation of compound 15 from 14a. mp. $96^{\circ} \mathrm{C}$; FT-IR $(\mathrm{KBr}) \mathrm{cm}^{-1} 2937$, 2388, 1769 (s), 1728 (s), 1623, 1378, 1236, 1200, 1044, 894, 755; ${ }^{1}$ H NMR (200 MHz, CDCl $): \delta 8.18$ (s, $\left.1 \mathrm{H}\right)$, 7.42 (d, $1 \mathrm{H}, J=2 \mathrm{~Hz}), 6.74$ (d, 1H, $J=2 \mathrm{~Hz}), 3.85$ (s, 3H), 2.12 (s, 6H); ${ }^{13} \mathbf{C}$ NMR $\left(50 \mathrm{MHz}, \mathrm{CDCl}_{3}\right): \delta 167.8$, 
162.3, 151.4, 143.0, 117.3, 112.2, 82.5, 51.9, 20.5; Anal. Calcd for $\mathrm{C}_{11} \mathrm{H}_{12} \mathrm{O}_{17}$ : C, 51.57; H, 4.72. Found: C, 51.92; H, 5.04 .

\subsection{Methyl 2-(Bis-phenylsulfanylmethyl)-furan-3-carboxylate (17)}

Method 1: This compound was obtained as white solid in $15 \%$ yield from 14a on treatment with $\mathrm{Ac}_{2} \mathrm{O}$ and $\mathrm{NaOAc}$, following the procedure adopted for the preparation of compound 15 from 14a.

Method 2: To a well stirred solution of 15 (200 mg, $1.19 \mathrm{mmol})$ and thiophenol (132 mg, $1.2 \mathrm{mmol})$ in dry $\mathrm{CHCl}_{3}(10 \mathrm{~mL})$ at rt was added TMSCl ( $\left.30 \mathrm{mg}, 0.28 \mathrm{mmol}\right)$ and stirring was continued for $5 \mathrm{~h}$. After completion of the reaction, this was washed with $5 \% \mathrm{NaHCO}_{3}$ solution $(20 \mathrm{~mL})$, diluted with water $(50 \mathrm{~mL})$, extracted with ethyl acetate $(3 \times 30 \mathrm{~mL})$. The combined organic phases were washed with brine $(25 \mathrm{~mL})$, dried $\left(\mathrm{Na}_{2} \mathrm{SO}_{4}\right)$ and concentrated under reduced pressure. Purification of the crude residue by chromatography on silica gel (1:2 ethyl acetate/petroleum ether, 0.68) gave 17 (360 mg, 85\%) as a thick oil. FT-IR (KBr) cm ${ }^{-1} 3140,1720$ (s), 1591, 1475 (m), 1441, 1312 (m), 1162, 1042, 747; ${ }^{1} \mathbf{H}$ NMR (200 MHz, $\left.\mathrm{CDCl}_{3}\right): \delta 7.35$ - 7.43 (m, 5H), 7.24 $7.30(\mathrm{~m}, 5 \mathrm{H}), 7.33$ (d, $1 \mathrm{H}, J=2 \mathrm{~Hz}), 6.35$ (s, $1 \mathrm{H}), 3.66$ (s, 3H); ${ }^{13} \mathbf{C}$ NMR $\left(50 \mathrm{MHz}, \mathrm{CDCl}_{3}\right): \delta$ 163.0, 156.9, 142.2, 133.3, 128.9, 128.3, 114.2, 110.4, 51.4, 50.8; HRMS: calcd. for $\mathrm{C}_{19} \mathrm{H}_{16} \mathrm{O}_{3} \mathrm{~S}_{2}[\mathrm{M}+\mathrm{H}]^{+}$357.0629; found 357.0636 .

\subsection{Methyl 2-Acetoxymethyl-furan-3-carboxylate (18)}

This compound was obtained as white solid in $15 \%$ yield from 14a on treatment with $\mathrm{Ac}_{2} \mathrm{O}$ and $\mathrm{NaOAc}$, following the procedure adopted for the preparation of compound 15 from 14a. mp. $47^{\circ} \mathrm{C}$; FT-IR $(\mathrm{KBr}) \mathrm{cm}^{-1} 1723$ (s), 1633 (s), 1387 (s), 1108 (m), 1041, 754; ${ }^{1} \mathbf{H}$ NMR (200 MHz, CDCl $)$ ): $\delta 7.37$ (d, $1 \mathrm{H}, J=2 \mathrm{~Hz}$ ), 6.70 (d, $1 \mathrm{H}$, $J=2 \mathrm{~Hz}$ ), 5.36 (s, 2H), 3.84 (s, 3H), 2.08 (s, 3H); ${ }^{13} \mathbf{C}$ NMR (50 MHz, $\left.\mathrm{CDCl}_{3}\right): \delta 170.1,163.1,154.3,142.6$, 116.9, 111.0, 56.8, 51.6, 20.6; HRMS: calcd. for $\mathrm{C}_{9} \mathrm{H}_{10} \mathrm{O}_{5}[\mathrm{M}+\mathrm{H}]^{+}$199.0608; found 199.0615.

\subsection{Methyl 2-Ethylsulfanylmethylfuran-3-carboxylate (20)}

To a stirred solution of ethanethiol $(0.16 \mathrm{~mL}, 2.15 \mathrm{mmol})$ in dry $\mathrm{CHCl}_{3}(5 \mathrm{~mL})$ and triethylamine $(217 \mathrm{mg}, 2.15$ mmol) at rt was added compound $12(470 \mathrm{mg}, 2.15 \mathrm{mmol})$. After overnight stirring, the resulting mixture was diluted with water $(130 \mathrm{~mL})$ and then extracted with chloroform $(3 \times 40 \mathrm{~mL})$, washed with $5 \%$ of $\mathrm{HCl}(20 \mathrm{~mL})$, brine $(30 \mathrm{~mL})$ and dried $\left(\mathrm{Na}_{2} \mathrm{SO}_{4}\right)$. The combined organic layer was concentrated under reduced pressure and purified by column chromatography on silica gel (1:10 chloroform/petroleum ether, $\left.\mathrm{R}_{\mathrm{f}} 0.42\right)$ to give $\mathbf{2 0}$ (375 mg, 87\%) as an oil. FT-IR (KBr) cm ${ }^{-1}$ 3434, 2953, 1722 (s), 1599, 1441, 1308 (m), 1210, 1063, 772; ${ }^{1} \mathbf{H}$ NMR (200 MHz, $\left.\mathrm{CDCl}_{3}\right): \delta 7.30$ (d, $\left.1 \mathrm{H}, J=2\right), 6.64(\mathrm{~d}, 1 \mathrm{H}, J=2.4 \mathrm{~Hz}), 4.07(\mathrm{~s}, 2 \mathrm{H}), 3.82(\mathrm{~s}, 3 \mathrm{H}), 2.55(\mathrm{q}, 2 \mathrm{H}, J=8 \mathrm{~Hz})$, 1.32 (t, 3H, $J=8 \mathrm{~Hz}) ;{ }^{13} \mathrm{C}$ NMR $\left(50 \mathrm{MHz}, \mathrm{CDCl}_{3}\right): \delta 163.8,158.8,141.3,113.9,110.6,51.6,26.5,25.9,14.4$; HRMS: calcd. for $\mathrm{C}_{9} \mathrm{H}_{12} \mathrm{O}_{3} \mathrm{~S}[\mathrm{M}+\mathrm{H}]^{+}$201.0587; found 201.0575.

\subsection{Methyl 2-Ethanesulfinylmethylfuran-3-carboxylate (21a)}

To a solution of compound 20 (2 g, $10 \mathrm{mmol})$ in $\mathrm{MeOH}(50 \mathrm{~mL})$ containing water $(5 \mathrm{~mL})$ was added solid $\mathrm{NaIO}_{4}(2.30 \mathrm{~g}, 10.7 \mathrm{mmol})$ in portions. The resultant mixture was stirred for $2 \mathrm{~h}$ at $0^{\circ} \mathrm{C}$ and the solvent was removed under reduced pressure. The resulting crude liquid was purified by column chromatography over silica gel (1:5 chloroform/petroleum ether, $\left.\mathrm{R}_{\mathrm{f}} 0.38\right)$ to furnish the sulfoxide $21 \mathrm{a}(1.20 \mathrm{~g}, 56 \%$, oily liquid) as the major product along with sulfone derivative 21b (33\%). FT-IR $(\mathrm{KBr}) \mathrm{cm}^{-1} 1717$ (s), 1654, 1559, 1508, 769; ${ }^{1} \mathbf{H}$ NMR $\left(200 \mathrm{MHz}, \mathrm{CDCl}_{3}\right): \delta 7.40$ (d, $\left.1 \mathrm{H}, J=2 \mathrm{~Hz}\right), 6.73(\mathrm{~d}, 1 \mathrm{H}, J=2 \mathrm{~Hz}), 4.44$ (ABq, $\left.2 \mathrm{H}, J=12 \mathrm{~Hz}\right), 3.85$ (s, 3H), $2.72(\mathrm{q}, 2 \mathrm{H}, J=8 \mathrm{~Hz}), 1.35$ (t, 3H, $J=8 \mathrm{~Hz}) ;{ }^{13} \mathbf{C}$ NMR (50 MHz, $\left.\mathrm{CDCl}_{3}\right): \delta 163.3$, 150.6, 143.0, 117.1, 110.9, 51.5, 49.1, 45.2, 6.2; HRMS: calcd. for $\mathrm{C}_{9} \mathrm{H}_{12} \mathrm{O}_{4} \mathrm{~S}[\mathrm{M}+\mathrm{H}]^{+}$217.0536; found 217.0542.

\subsection{Methyl 2-Ethanesulfonylmethylfuran-3-carboxylate (21b)}

This compound was obtained in the above experiment (for the preparation of 21a) as white solid in 33\% yield. mp. $90^{\circ}$ C; FT-IR (KBr) cm ${ }^{-1}$ 2940, 1711 (s), 1600, 1508, 1445, 1307, 1042, 827; ${ }^{1} \mathbf{H}$ NMR $\left(200 \mathrm{MHz}, \mathrm{CDCl}_{3}\right)$ : $\delta 7.46$ (d, 1H, $J=2 \mathrm{~Hz}$ ), 6.75 (d, 1H, $J=2 \mathrm{~Hz}$ ), 4.74 (s, 2H), 3.86 (s, 3H), 3.02 (q, 2H, $J=8 \mathrm{~Hz}$ ), 1.38 (t, 3H, $J$ $=8 \mathrm{~Hz}) ;{ }^{13} \mathrm{C}$ NMR $\left(50 \mathrm{MHz}, \mathrm{CDCl}_{3}\right): \delta 163.2,148.3,143.7,118.1,111.1,51.8,50.8,47.2,6.10$. Anal. Calcd 
for $\mathrm{C}_{9} \mathrm{H}_{12} \mathrm{NO}_{5} \mathrm{~S}$ : C, 46.54; H, 5.21. Found: C, 46.57; H, 5.04 .

\subsection{Methylsulfanylbenzene (23)}

A mixture of thiophenol 22 (5 g, $45.5 \mathrm{mmol}$ ) and 20\% of aqueous solution $\mathrm{NaOH}(50 \mathrm{~mL})$ was stirred for 30 min at rt. Then dimethyl sulfate $(4.28 \mathrm{~mL}, 45.5 \mathrm{mmol})$ was added to the reaction mixture and stirring was continued for $1 \mathrm{~h}$. Afterward, reaction mixture was heated at reflux for $7 \mathrm{~h}$, cooled to rt, extracted with $\mathrm{CH}_{2} \mathrm{Cl}_{2}(3 \times$ $40 \mathrm{~mL}$ ). The combined extracts were washed with $10 \%$ aq. $\mathrm{NaOH}$ solution $(30 \mathrm{~mL})$, dried $\left(\mathrm{Na}_{2} \mathrm{SO}_{4}\right)$ and distilled to give compound 23 [14] (4.9 g, 87\%) as colorless oil. ${ }^{1} \mathbf{H}$ NMR (200 MHz, $\left.\mathrm{CDCl}_{3}\right): \delta 7.32-7.28(\mathrm{~m}, 3 \mathrm{H}), 7.22$ - $7.16(\mathrm{~m}, 2 \mathrm{H}), 2.50(\mathrm{~s}, 3 \mathrm{H})$.

\subsection{Chloromethylsulfanylbenzene (24)}

To a stirred solution of compound $23(2 \mathrm{~g}, 6.10 \mathrm{mmol})$ in $\mathrm{CCl}_{4}(20 \mathrm{~mL})$ was added $N$-chlorosuccinimide (2.36 g, $6.71 \mathrm{mmol})$ at room temperature and stirring was continued for $11 \mathrm{~h}$. The reaction mixture then cooled $\left(0^{\circ} \mathrm{C}\right)$ and filtered off. The filtrate was then concentrated under reduced pressure and the residue distilled to give a brownish semisolid of 24 [15] (0.78 g, 82\%). ${ }^{1} \mathbf{H}$ NMR (200 MHz, $\left.\mathrm{CDCl}_{3}\right): \delta 7.58$ - 7.48 (m, 2H), $7.40-7.14$ (m, 3H), 4.97 (s, 2H).

\subsection{Phenylsulfanylmethyl Furan-3-carboxylate (26)}

To a stirred solution of 3-furoic acid (25) (1.0 g, $9.0 \mathrm{mmol})$ and DBU (1.36 g, $9.0 \mathrm{mmol})$ in dry acetonitrile (10 $\mathrm{mL}$ ) under inert atmosphere, was added compound $24(1.42 \mathrm{~g}, 9.0 \mathrm{mmol})$. The resulting mixture was further stirred for $4 \mathrm{~h}$ at $\mathrm{rt}$ and extracted with ethyl acetate $(3 \times 30 \mathrm{~mL})$. The combined ethyl acetate extracts were washed with saturated solution of $\mathrm{NaHCO}_{3}(20 \mathrm{~mL})$, brine $(20 \mathrm{~mL})$ and dried $\left(\mathrm{Na}_{2} \mathrm{SO}_{4}\right)$. Concentration of the organic layer gave a light yellow residue. This was purified by column chromatography (1:10 chloroform/petroleum ether, $\left.R_{\mathrm{f}} 0.60\right)$ to give $26(1.02 \mathrm{~g}, 70 \%)$ as an oily liquid. FT-IR (KBr) $\mathrm{cm}^{-1} 2930,1730$ (s), 1431, 1329, 1292, 1150 (s), 1126 (m)1078, 973, 749; ${ }^{1} \mathbf{H}$ NMR (200 MHz, CDCl $): \delta 8.04$ (d, $1 \mathrm{H}, J=2 \mathrm{~Hz}$ ), $7.42-7.55(\mathrm{~m}, 3 \mathrm{H}), 7.28$ - $7.38(\mathrm{~m}, 3 \mathrm{H}), 6.76(\mathrm{~d}, 1 \mathrm{H}, \mathrm{J}=2 \mathrm{~Hz}), 5.58(\mathrm{~s}, 2 \mathrm{H})$; HRMS: calcd. for $\mathrm{C}_{12} \mathrm{H}_{10} \mathrm{O}_{3} \mathrm{~S}[\mathrm{M}+$ $\mathrm{H}]^{+}$235.0431; found 235.0439.

\subsection{Benzenesulfinylmethyl Furan-3-carboxylate (27)}

To a stirred solution of compound $26(120 \mathrm{mg}, 0.74 \mathrm{mmol})$ in $\mathrm{MeOH}(10 \mathrm{~mL})$ containing water $(2 \mathrm{~mL})$ was added solid $\mathrm{NaIO}_{4}(170 \mathrm{mg}, 0.79 \mathrm{mmol})$ in portions. The resultant mixture was stirred for $5 \mathrm{~h}$ at $\mathrm{rt}$ and the solvent was removed under reduced pressure. The resulting crude liquid was extracted with ethyl acetate $(3 \times 20$ $\mathrm{mL})$. The combined ethyl acetate extracts was washed with brine $(20 \mathrm{~mL})$ and dried $\left(\mathrm{Na}_{2} \mathrm{SO}_{4}\right)$. Concentration of the organic layer gave a solid residue which was purified by column chromatography (1:5 chloroform/petroleum ether, $\left.\mathrm{R}_{\mathrm{f}} 0.52\right)$ to give 27 (140 mg, 76\%) as a white solid. mp. $84^{\circ} \mathrm{C}-85^{\circ} \mathrm{C}$; FT-IR (KBr) cm${ }^{-1}$ 2929, 1747 (s), 1571, 1315, 1169, 1122 (s), 1085 (m), 1049, 757; ${ }^{1} \mathbf{H}$ NMR (200 MHz, CDCl $): \delta 8.07$ (d, $\left.1 \mathrm{H}, J=2 \mathrm{~Hz}\right), 7.66$ $7.75(\mathrm{~m}, 2 \mathrm{H}), 7.52$ - $7.58(\mathrm{~m}, 3 \mathrm{H}), 7.41-7.47(\mathrm{~m}, 1 \mathrm{H}), 5.14(\mathrm{ABq}, 2 \mathrm{H}, J=12 \mathrm{~Hz}) ;{ }^{13} \mathrm{C}$ NMR $\left(50 \mathrm{MHz}, \mathrm{CDCl}_{3}\right)$ : $\delta$ 161.4, 148.8, 144.1, 140.3, 131.8, 129.4, 124.5, 117.5, 109.7, 81.9; HRMS: calcd. for $\mathrm{C}_{12} \mathrm{H}_{10} \mathrm{O}_{4} \mathrm{~S}[\mathrm{M}+\mathrm{H}]^{+}$ 251.0380; found 251.0388.

\subsection{Methyl 3-Dibromomethyl-furan-2-carboxylate (29)}

A mixture of commercially available methyl 3-methyl-2-furoate (28) (2.0 g, $14.30 \mathrm{mmol})$, NBS (5.08 g, 28.60 $\mathrm{mmol})$ and a pinch of benzoyl peroxide in $\mathrm{CCl}_{4}(150 \mathrm{~mL})$ was heated at reflux for $3.5 \mathrm{~h}$ under the exposure of a bulb $(100 \mathrm{~W})$. The reaction mixture was then cooled $\left(0^{\circ} \mathrm{C}\right)$ and succinimide filtered. The filtrate was concentrated under reduced pressure to give a yellowish residue which was then subjected to column chromatography over silica gel (60 - 120 mesh) using chloroform-petroleum ether mixture (3:7, v/v, $\mathrm{R}_{\mathrm{f}} 0.58$ ) as eluent to furnish dibromo compound 29 ( $2.54 \mathrm{~g}$, $60 \%$, white solid) as a main product along with $30(25 \%)$. mp. $80^{\circ} \mathrm{C}-82^{\circ} \mathrm{C}$; FTIR (KBr) cm ${ }^{-1}$ 3142, $1732(\mathrm{~s}), 1608,1420,1382,1252,1065$ (m), 875, 758; ${ }^{1} \mathbf{H}$ NMR $\left(200 \mathrm{MHz}, \mathrm{CDCl}_{3}\right): \delta$ 7.51 (d, $1 \mathrm{H}, J=2 \mathrm{~Hz}$ ), 7.36 (s, $1 \mathrm{H}), 6.92(\mathrm{~d}, 1 \mathrm{H}, J=2 \mathrm{~Hz}), 3.95$ (s, 3H); HRMS: calcd. for $\mathrm{C}_{7} \mathrm{H}_{6} \mathrm{Br}_{2} \mathrm{O}_{3}[\mathrm{M}+\mathrm{H}]^{+}$ 295.8684; found 295.8678 . 


\subsection{Methyl 3-Bromomethyl-2-carboxylate (30)}

This compound was obtained as white solid in $25 \%$ yield and co-product if 30 . mp. $51^{\circ} \mathrm{C}$ (lit. [16] $52^{\circ} \mathrm{C}-53^{\circ} \mathrm{C}$ ); ${ }^{1}$ H NMR (200 MHz, CDCl $)$ ): $\delta 7.50$ (d, 1H, $J=2 \mathrm{~Hz}$ ), 6.60 (d, 1H, $\left.J=2 \mathrm{H}\right), 4.65$ (s, 2H), 3.92 (s, 3H).

\subsection{Methyl 3-Formyl-furan-2-carboxylate (31)}

To a solution of compound 29 (1.28 g, $4.29 \mathrm{mmol})$ in THF $(20 \mathrm{~mL})$ was added aqueous solution of $\mathrm{AgNO}_{3}(1.45$ g, $8.58 \mathrm{mmol}$ in $5 \mathrm{~mL}$ water) in portions and stirring was continued for overnight at room temperature. The resulting mixture was filtered and after usual work-up of the concentrated filtrate, the residue was purified by column chromatography (1:8 ethyl acetate/petroleum ether, $\left.\mathrm{R}_{\mathrm{f}} 0.52\right)$ to give $31(0.28 \mathrm{~g}, 42 \%)$ as white crystalline solid. mp. $72^{\circ} \mathrm{C}-74^{\circ} \mathrm{C}$; FT-IR (KBr) cm ${ }^{-1}$ 3264, 2890, 1732 (s), 1682 (s), 1612, 1412, 1320, 1246, 1085, 756; ${ }^{1} \mathrm{H}$ NMR (200 MHz, $\left.\mathrm{CDCl}_{3}\right): \delta 10.51$ (s, $\left.1 \mathrm{H}\right), 7.54$ (d, $\left.1 \mathrm{H}, J=1.8\right), 6.90$ (d, $\left.1 \mathrm{H}, J=1.8\right), 4.0(\mathrm{~s}, 1 \mathrm{H})$.

\subsection{Methyl 3-(1,1-Diphenylsulfanyl)-methylfuran-2-carboxylate (32)}

This compound was prepared by reaction of $\mathbf{3 1}$ with thiophenol in $80 \%$ yield as yellow liquid, according to the procedure described for 17 from 15 (Method 2). FT-IR (KBr) cm ${ }^{-1}$ 3160, 1728 (s), 1592, 1470 (m), 1438, 1310 (m), 1140, 1102, 1046, 746; ${ }^{1} \mathbf{H}$ NMR (200 MHz, $\left.\mathrm{CDCl}_{3}\right): \delta 7.34-7.44(\mathrm{~m}, 5 \mathrm{H}), 7.22-7.30(\mathrm{~m}, 7 \mathrm{H}), 6.66(\mathrm{~d}$, $1 \mathrm{H}, J=2 \mathrm{~Hz}), 6.33$ (s, $1 \mathrm{H}), 3.78$ (s, 3H); ${ }^{13} \mathrm{C}$ NMR (50 MHz, $\left.\mathrm{CDCl}_{3}\right): \delta 158.9,145.2,138.9,133.9,133.5,132.8$, 128.8, 128.0, 112.5, 51.7, 49.6; MS $\mathrm{m} / \mathrm{z}$ (EI): [M + H] $]^{+} 357.0640$.

\subsection{4-Methyl-benzenesulfonyl Azide (34)}

This compound was prepared according to the procedure reported procedure [9]. A mixture of $p$-toluenesulfonyl chloride (33) (1.35 g, $7 \mathrm{mmol}), \mathrm{NaN}_{3}(0.55 \mathrm{~g}, 8.5 \mathrm{mmol})$ in aqueous solution of acetone (1:2 mixture of acetone andwater) were stirred for $5 \mathrm{~h}$ and then acetone was removed under reduced pressure. After usual work-up, drying $\left(\mathrm{Na}_{2} \mathrm{SO}_{4}\right)$, solvent was evaporated to furnish the desired product 34 [17] as light yellow liquid (1.17 g, 85\%), which was sufficiently pure for the next experiment. ${ }^{1} \mathbf{H}$ NMR $\left(200 \mathrm{MHz}, \mathrm{CDCl}_{3}\right): \delta 7.82(\mathrm{~d}, 2 \mathrm{H}, J=8), 7.32(\mathrm{~d}$, $2 \mathrm{H}, J=8), 2.45(\mathrm{~s}, 3 \mathrm{H})$.

\subsection{3-Diazotetrahydrofuran-2,4-dione (36)}

To a stirred solution of tetrahydrofuran-2,4-dione 35 ( $2.0 \mathrm{~g}, 0.02 \mathrm{~mol})$ and $p$-tosyl azide 34 ( $3.7 \mathrm{~g}, 0.02 \mathrm{~mol})$ in acetonitrile $(50 \mathrm{~mL})$ was added triethylamine $(2 \mathrm{~g}, 0.02 \mathrm{~mol})$ dropswise over $15 \mathrm{~min}$ resulting in a darkening of the solution. After one hour stirring at room temperature the reaction mixture was concentrated and extracted with ether $(3 \times 50 \mathrm{~mL})$. The combined organic phases were washed with $5 \%$ of $\mathrm{HCl}(20 \mathrm{~mL})$, brine $(25 \mathrm{~mL})$, dried $\left(\mathrm{Na}_{2} \mathrm{SO}_{4}\right)$ and concentrated under reduced pressure. Purification of the crude residue by chromatography on silica gel (1:1 ethyl acetate/petroleum ether, $\mathrm{R}_{\mathrm{f}} 0.61$ ) gave 36 [9] (1.0 g, 40\%) as a yellowish solid. $\mathbf{m p} .90^{\circ} \mathrm{C}$; FT-IR (KBr) cm ${ }^{-1}$ 2166, 1760 (s), 1692 (s); ${ }^{1} \mathbf{H}$ NMR (200 MHz, CDCl $): \delta 4.70$ (2H, s).

\subsection{Methyl 2-Hydroxymethylfuran-3-carboxylate (38)}

To a solution of DMSO and water $(100 \mathrm{~mL}, 90: 10, \mathrm{v} / \mathrm{v})$ at $80^{\circ} \mathrm{C}$ temperature was added compound $12(1.0 \mathrm{~g}$, $4.58 \mathrm{mmol}$ ) and stirring was continued for $4 \mathrm{~h}$. The resulting reaction mixture was extracted with diethyl ether (3 $\times 50 \mathrm{~mL}$ ). The combined extracts were dried $\left(\mathrm{Na}_{2} \mathrm{SO}_{4}\right)$ and the organic phase was evaporated under reduced pressure. The residue was subjected to column chromatography over silica gel (60 - 120 mesh) (1:10 ethyl acetate-petroleum ether, $R_{\mathrm{f}}$ 0.56) to furnish the alcohol 38 [11] (660 mg, 92\%) as brownish liquid. FT-IR (KBr) $\mathrm{cm}^{-1}$ 3448, 2925, 1724 (s), 1438, 1260, 1024, 762; ${ }^{1} \mathrm{H}$ NMR (200 MHz, CDCl 3 ): $\delta 7.27$ (d, $1 \mathrm{H}, J=1.6 \mathrm{~Hz}$ ), 6.64 (d, $1 \mathrm{H}, J=1.6 \mathrm{~Hz}$ ), 4.78 (s, 2H), 3.83 (s, 3H); ${ }^{13}$ C NMR (50 MHz, $\left.\mathrm{CDCl}_{3}\right): \delta 164.96,161.25,141.26,114.86$, 110.75, 57.23, 51.89; MS m/z (EI): $[\mathrm{M}+2 \mathrm{H}]^{+}$158.0267, [M + Na-OMe] ${ }^{+}$149.0236, $[\mathrm{M}+2 \mathrm{H}-\mathrm{OH}]^{+} 141.0020$.

\subsection{2-Hydroxymethylfuran-3-carboxylic acid (39)}

Hydroxy ester compound 38 ( $0.78 \mathrm{~g}, 5 \mathrm{mmol})$ was treated with a mixture of $15 \%$ solution of aqueous KOH (15 $\mathrm{mL})$ and methanol $(30 \mathrm{~mL})$ for $2 \mathrm{~h}$ at rt. On completion of the reaction, $5 \%$ of $\mathrm{HCl}$ solution $(20 \mathrm{~mL})$ was added dropwise till $\mathrm{pH}$ 6.5. A white solid separated out from the reaction mixture, which was filtered and washed tho- 
roughly with water to furnish pure acid derivative 39 (640 mg, 90\%) as white solid. mp. $76^{\circ} \mathrm{C}-78^{\circ} \mathrm{C}$ FT-IR (KBr) $\mathrm{cm}^{-1}$ 3455, 2924, 1686 (s), 1551 (m), 1269, 1166, 1375, 743; ${ }^{1}$ H NMR (200 MHz, $\mathrm{d}_{6}$-DMSO): $\delta 7.40$ (d, $1 \mathrm{H}, J=2 \mathrm{~Hz}), 6.75$ (d, $1 \mathrm{H}, J=2 \mathrm{~Hz}), 4.81$ (s, $1 \mathrm{H}), 2.59$ (d, $1 \mathrm{H}, J=2 \mathrm{~Hz}) ;{ }^{13} \mathbf{C}$ NMR (50 MHz, $\mathrm{d}_{6}$-DMSO): $\delta$ 169.54, 165.18, 147.36, 119.82, 116.04, 59.50. HRMS: calcd. for $\mathrm{C}_{6} \mathrm{H}_{6} \mathrm{O}_{4}[\mathrm{M}+\mathrm{Na}]^{+}$165.0156; found 165.0166.

\subsection{4-Hydroxy-7,8-dihydro-6H-naphtho[2,3-b] furan-5-one (42)}

To a stirred solution of lithium tert-butoxide $(2.42 \mathrm{mmol})$ in THF $(10 \mathrm{~mL})$ at $-60^{\circ} \mathrm{C}$ (chloroform/liquid $\mathrm{N}_{2}$ bath) under an inert atmosphere was added a solution of furansulfoxide (200 mg, $0.75 \mathrm{mmol}$ ) in THF $(1.5 \mathrm{~mL})$. The resulting yellowish solution was stirred at $-60^{\circ} \mathrm{C}$ for $25 \mathrm{~min}$, after which a solution of a 2-cyclohexenone $(0.90$ $\mathrm{mmol})$ in THF $(1.5 \mathrm{~mL})$ was added to it. The cooling bath was removed after about $1 \mathrm{~h}$ at $-60^{\circ} \mathrm{C}$ and the reaction mixture was brought to room temperature over a period of $1 \mathrm{~h}$ and further stirred for $5 \mathrm{~h}$. The reaction was then quenched with $10 \% \mathrm{NH}_{4} \mathrm{Cl}(10 \mathrm{~mL})$ and the resulting solution was concentrated under reduced pressure. The residue was diluted with ethyl acetate $(20 \mathrm{~mL})$ and the layers were separated. The aqueous layer was extracted with ethyl acetate $(3 \times 15 \mathrm{~mL})$. The combined extracts were washed with brine $(3 \times 1 / 3 \mathrm{vol}$.), dried $\left(\mathrm{Na}_{2} \mathrm{SO}_{4}\right)$ and concentrated to provide crude product. The crude solid product was purified by column chromatography on silica gel to give compound $42(10 \mathrm{mg}, 7 \%)$ as white solid. mp. $118^{\circ} \mathrm{C}-20^{\circ} \mathrm{C}$; FT-IR $(\mathrm{KBr}) \mathrm{cm}^{-1}$ 3405, 2940, 2502, 2375, 1982, 1630 (s), 1450, 1450 (m), 1356, 1331, 1284, 11285, 1120 (m), 1014, 814, 747; ${ }^{1} \mathbf{H}$ NMR (200 MHz, $\left.\mathrm{CDCl}_{3}\right): \delta 13.51(\mathrm{~s}, 1 \mathrm{H}), 7.49(\mathrm{~d}, 1 \mathrm{H}, J=2 \mathrm{~Hz}), 6.94(\mathrm{~d}, 1 \mathrm{H}, J=0.8 \mathrm{~Hz}), 6.84(\mathrm{~s}, 1 \mathrm{H}), 2.97$ - 3.10 (m, 2H), 2.66 - 2.74 (m, 2H), $2.05-2.18(\mathrm{~m}, 2 \mathrm{H})$.

\section{Acknowledgements}

Financial support from the UGC Minor Research Grant, F. PSW-092/11-12 (ERO) dated $3^{\text {rd }}$ August, 2011, New Delhi is gratefully acknowledged.

\section{References}

[1] Lin, K.I., Su, J.C., Chien, C.M., Tseng, C.H., Chen, Y.L., Chang, L.S. and Lin, S.R. (2010) Naphtho[1,2-b]furan-4,5dione Induces Apoptosis and S-Phase Arrest of MDA-MB-231 Cells through JNK and ERK Signaling Activation. Toxicology in Vitro, 24, 61-70. http://dx.doi.org/10.1016/j.tiv.2009.09.002

Ito, C., Katsuno, S., Kondo, Y., Tan, H.T.W. and Furukawa, H. (2000) Chemical Constituents of Avicennia Alba. Isolation and Structural Elucidation of New Naphthoquinones and Their Analogues. Chemical \& Pharmaceutical Bulletin, 48, 339-343.

Hirai, K., Koyama, J., Pan, J., Simamura, E., Shimada, H. and Yamori, T. (1999) Cancer Detection and Prevention, 23, 539-550.

Nagata, K., Hirai, K., Koyama, J., Wada, Y. and Tamura, T. (1998) Antimicrobial Agents and Chemotherapy, 42, 700-702.

Takegami, T., Simamura, E., Hirai, K. and Koyama, J. (1998) Inhibitory Effect of Furanonaphthoquinone Derivatives on the Replication of Japanese Encephalitis Virus. Antiviral Research, 37, 37-45.

[2] Inagaki, R., Ninomiya, M., Tanaka, K., Watanabe, K. and Koketsu, M. (2013) Synthesis and Cytotoxicity on Human Leukemia Cells of Furonaphthoquinones Isolated from Tabebuia Plants. Chemical \& Pharmaceutical Bulletin, 61, 670-673. http://dx.doi.org/10.1248/cpb.c13-00011

[3] Thomson, R.H. (1997) Naturally Occurring Quinones IV, Recent Advances. Blackie Academics \& Professional, London, 112-308.

Diaz, F. and Medina, J.D. (1996) Furanonaphthoquinones from Tabebuia ochracea ssp. Neochrysanta. Journal of Natural Products, 59, 423-424.

Corral, J.M.D., Castro, M., Oliveira, A., Gualberto, S., Cuevas, C. and San, A.F. (2006) New Cytotoxic Furoquinones Obtained from Terpenyl-1,4-naphthoquinones and 1,4-Anthracenediones. Bioorganic \& Medicinal Chemistry, 14, 7231-7240.

Kobayashi, K., Uneda, T., Kawakita, M., Morikawa, O. and Konishi, H. (1997) One-Pot Synthesis of Naphtho[2,3-b] furan-4,9-diones by Sequential Coupling/Ring Closure Reactions. Tetrahedron Letters, 38, 837-840.

[4] Kobayashi, K., Shimizu, H., Sakai, A. and Suginome, H. (1993) Photoinduced Molecular Transformations. 140. New One-Step General Synthesis of Naphtho[2,3-b]furan-4,9-diones and Their 2,3-Dihydro Derivatives by the Regioselective [3 + 2] Photoaddition of 2-Hydroxy-1,4-naphthoquinones with Various Alkynes and Alkenes: Application of the Photoaddition to a Two-Step Synthesis of Maturinone. Journal of Organic Chemistry, 58, 4614-4618.

http://dx.doi.org/10.1021/jo00069a023 
Kobayashi, K., Kanno, Y. and Suginome, H. (1993) Photoinduced Molecular Transformations. Part 141. New OneStep General Synthesis of Benzofuran-4,7-diones by the Regioselective $(3+2)$ Photoaddition of 2-Hydroxy-1,4-benzoquinones with Various Alkenes. Journal of the Chemical Society, Perkin Transactions, 1, 1449-1452.

Lee, Y.R., Suk, J.Y. and Kim, B.S. (2000) One-Pot Construction of Medium- and Large-Sized Ring Substituted Furans. Efficient Conversion to Dibenzofurans, Coumestans, and 4-Pyrones. Organic Letters, 2, 1387-1389.

[5] Hauser, F.M., Dorsch, W.A. and Mal, D. (2002) Total Synthesis of ( \pm )-O-Methyl PD 116740. Organic Letters, 4, 2237-2239.

Mal, D., Senapati, B.K. and Pahari, P. (2006) Regioselective Synthesis of 1-Hydroxycarbazoles via Anionic [4 + 2] Cycloaddition of Furoindolones: A Short Synthesis of Murrayafoline-A. Tetrahedron Letters, 47, 1071-1075.

http://dx.doi.org/10.1016/j.tetlet.2005.12.048

Mal, D., Senapati, B.K. and Pahari, P. (2007) Anionic [4 + 2] Cycloaddition Strategy in the Regiospecific Synthesis of Carbazoles: Formal Synthesis of Ellipticine and Murrayaquinone A. Tetrahedron, 63, 3768-3781. http://dx.doi.org/10.1016/j.tet.2007.02.060 Mal, D. and Pahari, P. (2007) Recent Advances in the Hauser Annulation. Chemical Reviews, 107, 1892-1918.

[6] Mal, D., Bandhyopadhyay, M., Datta, K. and Murty, K.V.S.N. (1998) Anionic [4 + 2] Cycloaddition Strategy to Linear Furocoumarins: Synthesis of 8-Methoxypsoralen and Its Isoster. Tetrahedron, 54, 7525-7538. http://dx.doi.org/10.1016/S0040-4020(98)00387-1

[7] Feldman, K.S. (2006) Modern Pummerer-Type Reactions. Tetrahedron, 62, 5003-5034. http://dx.doi.org/10.1016/j.tet.2006.03.004 Padwa, A. (2004) Tandem Methodology for Heterocyclic Synthesis. Pure and Applied Chemistry, 76, $1933-1952$. Bur, S.K. and Padwa, A. (2004) The Pummerer Reaction: Methodology and Strategy for the Synthesis of Heterocyclic Compounds. Chemical Reviews, 104, 2401-2432.

[8] Padwa, A., Danca, M.D., Hardcastle, K.I. and McClure, M.S. (2003) A Short Diastereoselective Synthesis of the Putative Alkaloid Jamtine, Using a Tandem Pummerer/Mannich Cyclization Sequence. Journal of Organic Chemistry, 68, 929-941.

Hauser, F.M., Rhee, R.P. and Prasanna, S. (1980) ortho-Toluate Carbanion Chemistry: Sulfenylation and Selenation. Synthesis, 1, 72-74. http://dx.doi.org/10.1055/s-1980-28963

[9] Murphy, P.V., O’Sullivian, T.J., Kenndy, B.D. and Geraghty, N.W. (2000) The Reactions of Diazo Compounds with Lactones. Part 2. The Reaction of Cyclic 2-Diazo-1,3-dicarbonyl Compounds with Diketene: Benzofuranformation. Journal of the Chemical Society, Perkin Transactions, 1, 2121-2126. http://dx.doi.org/10.1039/b001394n

[10] Pirrung, M.C. and Lee, Y.R. (1994) Dipolar Cycloaddition of Rhodium Carbenoids with Vinyl Esters. Total Synthesis of Pongamol and Lanceolatin B. Tetrahedron Letters, 35, 6231-6234. http://dx.doi.org/10.1016/S0040-4039(00)73399-5

[11] Pevzner, L.M. (2001) Synthesis and Properties of (1,3-Dioxolan-2-yl)furans. Russian Journal of General Chemistry, 71, 1045-1049. http://dx.doi.org/10.1023/A:1013149519992

[12] Parr, R.G. and Yang, W. (1989) Density Functional Theory of Atoms and Molecules. Oxford University Press, Oxford.

[13] Khatuya, H. (2001) On the Bromination of Methyl 2-Methyl-3-Furoate. Tetrahedron Letters, 42, 2643-2644. http://dx.doi.org/10.1016/S0040-4039(01)00275-1

[14] Yamamoto, T. and Sekine, Y. (1984) Condensation of Thiophenols with Aryl Halides Using Metallic Copper as a Reactant. Intermediation of Cuprous Thiophenolates. Canadian Journal of Chemistry, 62, 1544-1547. http://dx.doi.org/10.1139/v84-263

[15] Tanikaga, R., Miyashita, K., Ono, N. and Kaji, A. (1982) A Convenient Synthesis of 2-Alkenoic Esters. Synthesis, 1982, 131-132. http://dx.doi.org/10.1055/s-1982-29714

[16] Clayden, J., Greeves, N., Warren, S. and Wothers, P. (2001) Organic Chemistry. Oxford University Press Inc., New York, 1133.

Vegh, D., Morel, J., Decroix, B. and Zalupsky, P. (1992) A New Convenient Method for Preparation of Condensed Aromatic and Heterocyclic Thiolactones. Synthetic Communications, 22, 2057-2061. http://dx.doi.org/10.1080/00397919208021340

[17] Curphey, T.J. (1998) Preparation of p-Toluenesulfonyl Azide. A Cautionary Note. Organic Preparations and Procedures International, 13, 112-115. http://dx.doi.org/10.1080/00304948109356105 